\title{
Strategic Planning of Regional Sustainable Development Using Factor Analysis Method
}

\author{
Marija Milenković ${ }^{1}$, Ashok Vaseashta ${ }^{2}$, Dejan Vasović ${ }^{3 *}$ \\ ${ }^{1}$ University of Niš, Univerzitetski trg 2, Niš, Serbia \\ ${ }^{2}$ International Clean Water Institute, Manassas, VA and NJCU - State University of New Jersey, NJ USA \\ ${ }^{3}$ University of Niš, Faculty of Occupational Safety in Niš, Čarnojevića 10a, Niš, Serbia
}

Received: 24 February 2020

Accepted: 28 June 2020

\begin{abstract}
Sustainable development of a regional and local community involves setting a strategic balance among economic, social, and environmental criteria (factors) of development. Due to their large number, physical quantity variance, and incompleteness, these factors have a limited, sometimes even conflicting and ineffectual application in producing a unified effect on development. This issue becomes resolvable through a modification of factor analysis by means of combining it with multi-criteria decision analysis (MCDA). The solutions thus obtained in the form of a ranking, with the top-ranked solution being the most favorable, constitute immense support for decision makers to use the proposed most favorable solution to formulate and implement their plan of development.
\end{abstract}

Keywords: sustainable regional development, development factors, multi-criteria decision analysis, multi-objective planning, factor analysis

\section{Introduction}

Regional development is one of the frequent topics of interest not only within economic sciences but also among other subjects who are involved in decisionmaking concerning prosperity and preservation of values in a specific region. One of these values is the natural basis of development. Economically, a natural resource is something that is capable of creating an added-value. Environmentally, this is a justified goal, but only if such creation preserves the environment and potentially improves and enhances it.

There is no doubt that there is an interaction between the natural environment and the economic system. On

*e-mail: djnvasovic@gmail.com the one hand, natural resources are used for the purpose of production, but in order to attain sustainability, it is necessary to invest in the natural environment, as it is the only way to achieve harmonious development. This leads to a conclusion that economic sustainability in itself is insufficient for an overall long-term sustainability of a society. Sustainable development needs to meet the current demands of local, regional, and any other type of economic development but must also not neglect the needs of future generations in terms of preserving the environment. According to such a concept of sustainable development, the accomplishment of the set goals requires a strategic and practical approach.

Many issues pertaining to regional development have already been determined but are yet to be sufficiently investigated. The practice constantly unearths new 
issues, which require theoretical investigation and practical verification, thus suggesting that the general issue of regional development is highly complex and still underexplored.

According to the available theoretical and practical knowledge, there are multiple approaches to the analysis of the state of and the choice of solutions for regional sustainable development; the most frequently highlighted approaches include the factor approaches, the industrial-sector and regional approach, as well as approaches based on the monitoring of core determinants of economic growth rates and sustainable development that are important for raising the standard of living [1]. Any of the aforementioned approaches is influenced by numerous parameters, which need to be analyzed, systematized, and processed before they are used to create plans of development.

With proper modification, the factor model is the closest to a full systems approach that equally analyzes all the relevant factors of development. What makes the current factor model incomplete and under-researched is its insufficient methodological clarity regarding the coordination of all factors that influence the choice of the most favorable scenario of regional sustainable development. This paper presents a modality using modified methodology of the factor model for the purpose of planning regional sustainable development, which introduces the mechanism of quantification of all factors influencing development, their physical quantity harmonization, and their use in the multi-criteria decision analysis (MCDA) when determining the most favorable solution for development.

\section{Experimental Methodology}

\section{The Concept of Sustainable Development}

The concept of sustainable development has become an unavoidable factor in analyses and planning of regional development. Fundamentally, the concept is based on the connection that has to be established between economic development, social prosperity, and environmental quality. These requirements had been the subject of lengthy investigations, involving a number of experts in the aforementioned fields, which ultimately led to the constitution of the World Commission on Environment and Development [10], as proposed by the UN General Assembly and chaired by Gro Harlem Bruntland. The Commission prepared and published a report entitled Our Common Future in 1987. At the Rio de Janeiro Earth Summit in 1992, this document was designated as the key document for adopting the Rio Declaration on Environment and Development, which officially introduced the term sustainable development and its framework, connecting the environmental issues with the most significant social aspects of development. The Commission's report has since often been cited in literature as the "Bruntland Report", along with its definition of sustainable development as "development that meets the needs of the present without compromising the ability of future generations to meet their own needs."

The definition clearly highlights the three basic components of sustainable development: economic, social, and environmental, which are all connected and interdependent. This creates the need for their unified analysis and a single decision that would meet their requirements. Several auxiliary documents were also adopted at the Rio Summit and have remained current to this day in terms of their content and goals. One document - Agenda 21 - is particularly prominent, as it comprehensively elaborates the concept of sustainable development and the strategy of necessary changes in the attitude towards nature and development as humanity approached the $21^{\text {st }}$ century.

The operationalization and implementation of the concept of sustainable development after the Summit involved every responsible subject (primarily the governments of UN member states), and the results were analyzed at subsequent gatherings (the UN Millennium Summit in New York City in 2000; the Earth Summit 2002 in Johannesburg; the Rio+20 UN Conference on Sustainable Development in 2012; the UN Climate Change Conference in Paris in 2015 with Agenda 2030), as well as during numerous EU, regional, and national conferences.

Republic of Serbia has been an active participant in the enactment and implementation of documents, declarations, strategies, and other documents adopted at the aforementioned summits and conferences dedicated to the environment and sustainable development.

The following documents have been adopted via state legislation:

- Law on Environmental Protection [11] with special emphasis on water resources, forests, agricultural land, fish and game, national parks, and hazardous materials;

- National Sustainable Development Strategy of the Republic of Serbia2009-2017, with the Action Plan for its implementation [12];

- National Strategy for Sustainable Use of Natural Goods and Resources [13].

These documents incorporate all the Millennium Development Goals (2000) that serve to combat poverty and underdevelopment, to promote further economic growth and healthy environment, and to improve the social standards (healthcare, education, and social security). After the adoption of Agenda 2030 at the UN Climate Change Conference in Paris in 2015 [14], which defined 17 sustainable development goals for the following 15 years, Republic of Serbia began to analyze (map) the state of a feasible framework for sustainable development from its National Strategy, thus initiating its harmonization with the goals from the Agenda.

For the purpose of mapping, the said 17 sustainable development goals were divided into four groups:

1. Economic growth (Agenda goals 8 and 9); 

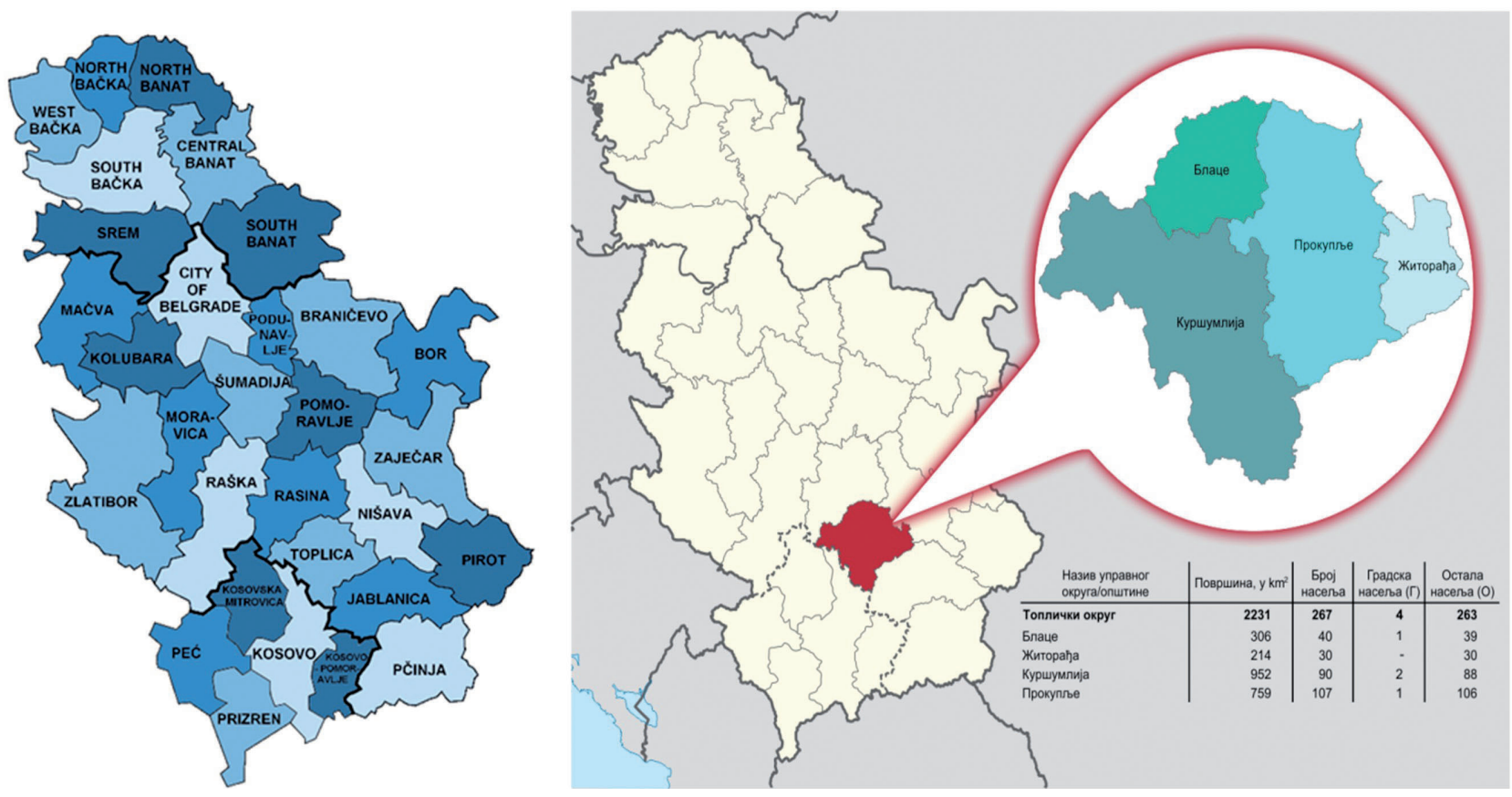

Fig. 1. Geographic location of the Toplica District (http://www.toplicki.okrug.gov.rs/wp- content /uploads/2015/12/mapa.png).

2. Human resource development (Agenda goals 1, 2, 3, 4, 5, and 10);

3. Environment and climate (Agenda goals 6, 7, 11, 12, 13, and 15);

4. Institutions, finance, and partnerships (Agenda goals 16 and 17).

This classification is used below when selecting the key factors (goals) of regional and sustainable development required for the factor analysis and the methodology that yields the most favorable solutions for the sustainable development of the Toplica District. The Toplica District has been selected as the target region to use the proposed methodology because it represents an almost ideal example of a region facing the challenges of sustainable development. Demographically, it is a depopulated region burdened by negative population growth and migration. Economically, it is one of the districts with the lowest income per capita and an underdeveloped and under diversified economy. Environmentally, it is a district with a rich biodiversity and forest resources and a modest specific yield of water resources per capita. The macro-location of the Toplica district is shown in Fig. 1.

The Toplica District is located in the southern part of Serbia and is named after the Toplica river, whose drainage basin almost completely corresponds to the administrative borders of the district. It is an underdeveloped area with prominent demographic depopulation, but it is also rich in natural resources for development such as soil and forested land suitable for agricultural and processing industry development, as well as thermal and mineral water springs, and it has good infrastructural connections within and outside the district and a high level of environmental preservation.
Factors of Regional and Sustainable Development

A modern approach to regional and sustainable development requires creating a balance between economic, social, and environmental components. Economic components of sustainable development are defined through growth, productivity, and just distribution of wealth.

Social components include participation in decision making and fostering of social well-being for all population groups. Environmental components include the preservation of physical and biological diversity and protection of natural resources.

According to the available information $[2,12,14$, 15] and practical experience concerning the use of factor analysis for the planning of regional sustainable development, the following groups of influencing factors should be used to cover the aforementioned components of sustainable development:

1. Natural factors (soil, forests, water, mineral raw materials);

2. Human factors (population structure by demographic parameters, educational qualification, and level of education);

3. Economic factors (agriculture, processing industry, services, and tourism);

4. Social factors (infrastructure, healthcare, education, and culture);

5. Ecological factors and the environment (soil, water, and forest protection and solid waste disposal).

Most of these factors are quantifiable and subject to numerical analysis. Non-quantifiable are usually assessed and expressed experientially. The analysis 
of integrated impact of the aforementioned and other factors on development, in terms of both their number and their physical quantity variance, is currently only possible using some of the methods of factor analysis, which have been developed according to the principles of MCA and optimization. This way, the factor analysis can be used more widely and the results thereby obtained provide a clearer direction for regional sustainable development planning.

\section{Results and Discussion}

\section{Multi-Criteria Decision Analysis of the Factors of Regional Development}

Regional development planning based on sustainability principles should be founded on the analysis of the state and possibilities of each of the region's local community (municipality) and of the region as a whole, as influenced by the selected economic, social, and environmental factors of development [16].

Out of numerous mathematical methods developed for the purpose of solving multi-criteria problems, which include regional development, the present study focuses on the group of methods for multi-attribute decision making (MADM), or more commonly, multicriteria decision analysis (MCDA). The most prominent methods from this group include PROMETHEE, analytic hierarchy process (AHP), ELECTRE, and VICOR, which offer solutions in the form of ranking of alternatives, providing the best alternative or a set of alternatives that meet the specified conditions [3].

The diagram of basic phases of problem solving using the MCDA methods is shown in Fig. 2.

Each of these methods defines the initial problem (e.g. regional sustainable development) by way of an initial decision matrix, which comprises the possible alternatives with the factors (criteria) influencing their development (Table 1).
Translation of the initial matrix with different physical quantities into a normalized or dimensionless form varies mathematically among the listed methods. After the analysis, this can create uncertainty regarding the method used and the suitability and certainty of the proposed most favorable alternative solution for development.

The ELECTRE method processes the initial decision matrix through multiple steps:

1. Normalizing the decision matrix;

2. Weighting the normalized decision matrix;

3. Determining the concordance and discordance sets;

4. Building the concordance and discordance matrices;

5. Determining the concordance and discordance of dominance matrices;

6. Determining the aggregate dominance matrix;

7. Disposing of the less favorable alternatives.

The VICOR method processes the initial decision matrix until the final solution through the following steps:

1. Normalizing the matrix;

2. Calculating the weight coefficients;

3. Calculating the final decision matrix;

4. Ranking the alternatives;

5. Selecting the most favorable solution.

It is therefore recommended that the initial problem be solved using at least two MCDAs would eliminate the uncertainty and verify the confirmed solution for further use in the actual planning of regional and sustainable development (Table 2).

Due to the advantages offered by the presented factor analysis model, it can be concluded that the model is applicable to other problems that are relevant for creating plans. The problem from Tables 1 and 2 (Toplica District) would certainly benefit from the recommendation based on the ranking of priority economic branches that need to be developed in order to further improve the current state of sustainable development.

The following groups of development factors are particularly prominent in the District: educational qualification of active population, agricultural and arable

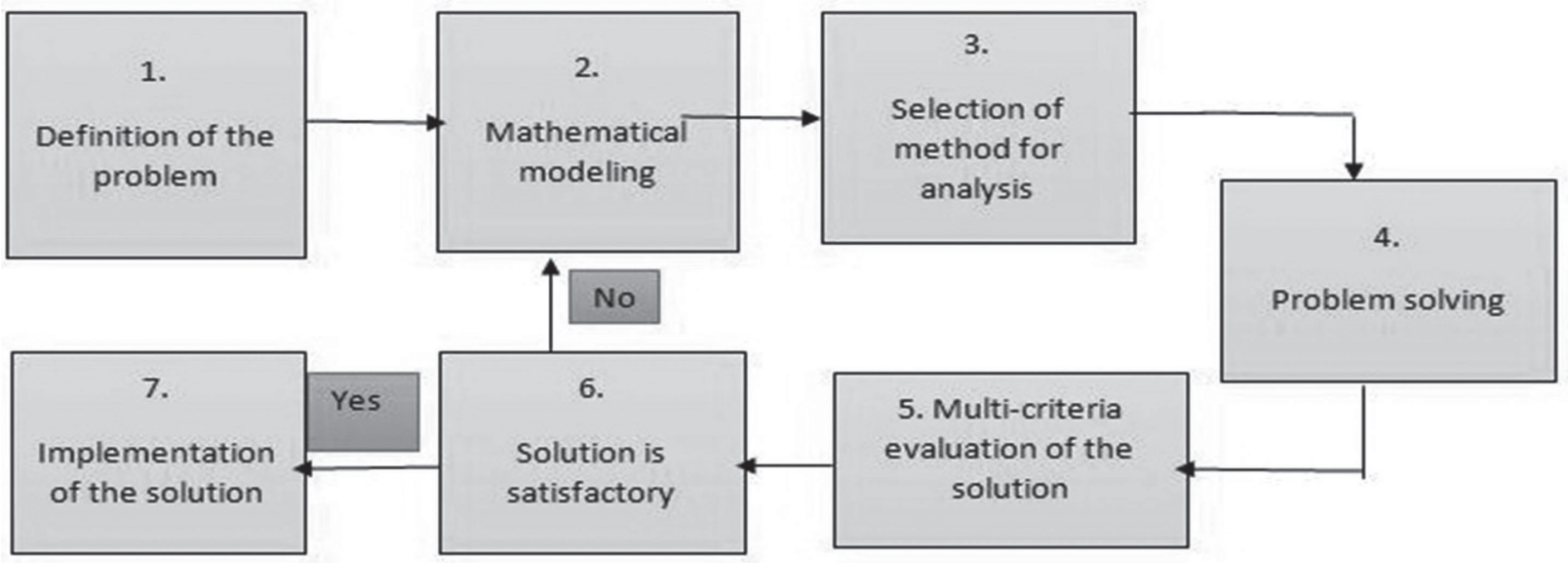

Fig. 2. Basic phases of the mathematical model for problem solving. 
Table1. Initial decision matrix for sustainable development of the Toplica District [4, 5].

\begin{tabular}{|c|c|c|c|c|c|c|c|}
\hline \multirow{2}{*}{\multicolumn{3}{|c|}{ Development criteria $\quad$ Alternatives }} & \multicolumn{4}{|c|}{ Municipalities } & \multirow{2}{*}{$\begin{array}{l}\text { Toplica } \\
\text { District }\end{array}$} \\
\hline & & & $\begin{array}{c}\text { a1 } \\
\text { Kuršumlija }\end{array}$ & $\begin{array}{c}\text { a2 } \\
\text { Blace }\end{array}$ & $\begin{array}{c}\text { a3 } \\
\text { Prokuplje }\end{array}$ & $\begin{array}{c}\text { a4 } \\
\text { Žitorađa }\end{array}$ & \\
\hline No. & $\begin{array}{l}\max \\
\min \end{array}$ & \multicolumn{6}{|c|}{ 1) Population number } \\
\hline & & Total in 2011 & 21,600 & 13,740 & 48,491 & 18,171 & 102,002 \\
\hline \multirow{2}{*}{1} & \multirow{2}{*}{$\max$} & Active & 7,052 & 5,551 & 15,062 & 5,593 & 31,708 \\
\hline & & $(\%)$ & $32.6 \%$ & $44 \%$ & $31 \%$ & $31 \%$ & $31 \%$ \\
\hline \multirow[t]{2}{*}{2} & $\max$ & Level of education & $\begin{array}{c}16,401 \\
2,64\end{array}$ & $\begin{array}{c}10,284 \\
2,63\end{array}$ & $\begin{array}{c}37,531 \\
2,65\end{array}$ & $\begin{array}{l}13,826 \\
224\end{array}$ & $\begin{array}{c}78,042 \\
2,54\end{array}$ \\
\hline & & \multicolumn{6}{|c|}{ 2) Economy - activity of employed population ( $\%$ of active population) } \\
\hline 3 & $\max$ & Agriculture & $55.1 \%$ & $61.3 \%$ & $44 \%$ & $55.3 \%$ & $50.7 \%$ \\
\hline 4 & $\max$ & Industry; Services & $29.1 \%$ & $25.4 \%$ & $33 \%$ & $31.2 \%$ & $30.7 \%$ \\
\hline \multirow[t]{2}{*}{5} & $\min$ & State-funded institutions & $15.8 \%$ & $13.3 \%$ & $23 \%$ & $13.5 \%$ & $18.5 \%$ \\
\hline & & \multicolumn{6}{|c|}{ 3) Social Standard } \\
\hline 6 & $\max$ & $\begin{array}{l}\text { Healthcare ( } 1 \text { physician per } \\
\text { population) }\end{array}$ & $1 / 537$ & $1 / 581$ & $1 / 372$ & $1 / 918$ & $1 / 372$ \\
\hline 7 & $\max$ & $\begin{array}{c}\text { Education (schools per number of } \\
\text { settlements) }\end{array}$ & $14 / 90$ & $20 / 40$ & $36 / 107$ & $21 / 30$ & $93 / 267$ \\
\hline \multirow[t]{2}{*}{8} & $\max$ & Infrastructure - roads & $556.85 \mathrm{~km}$ & $200.20 \mathrm{~km}$ & $339.57 \mathrm{~km}$ & $94.00 \mathrm{~km}$ & $1190.62 \mathrm{~km}$ \\
\hline & & \multicolumn{6}{|c|}{ 4) Ecology and the environment } \\
\hline \multirow{2}{*}{9} & \multirow{2}{*}{$\max$} & Agricultural land area & 14,127 ha & 10,339 ha & 17,789 ha & 9,297 ha & 51,553 ha \\
\hline & & Hectares per household & $3.77 \mathrm{ha} / \mathrm{hh}$ & $3.18 \mathrm{ha} / \mathrm{hh}$ & $3.2 \mathrm{ha} / \mathrm{hh}$ & $2.47 \mathrm{ha} / \mathrm{hh}$ & $3.16 \mathrm{ha} / \mathrm{hh}$ \\
\hline \multirow[t]{2}{*}{10} & \multirow[t]{2}{*}{$\max$} & $\begin{array}{l}\text { Water supply (liters per capita per } \\
\text { day against the avg. of } 1501 \text { ) }\end{array}$ & $841 \mathrm{pcd} / 150$ & $1331 \mathrm{lpcd} / 150$ & 1291pcd/150 & $161 \mathrm{pcd} / 150$ & $981 \mathrm{pcd} / 150$ \\
\hline & & Supply \% & $56 \%$ & $87 \%$ & $86 \%$ & $11 \%$ & $66 \%$ \\
\hline \multirow{2}{*}{11} & \multirow{2}{*}{$\max$} & Total forest area & 54,647 ha & 11,672 ha & $31,233 \mathrm{ha}$ & 2,356 ha & 99,909 ha \\
\hline & & Exploitation \% & $1.4 \%$ & $1.9 \%$ & $1.6 \%$ & $0.8 \%$ & $1.5 \%$ \\
\hline 12 & $\max$ & $\begin{array}{c}\% \text { of organized solid waste } \\
\text { collection }\end{array}$ & $45 \%$ & $50 \%$ & $55 \%$ & $50 \%$ & $50 \%$ \\
\hline
\end{tabular}

Sources: RZS (Statistical Office of the Republic of Serbia), 2011, Belgrade; Author

land, and sustainable use of natural resources. The prominent branches of economic development include agriculture, livestock breeding, processing industry, the service sector, and tourism. Initial decision matrices for the rankings of economic branches of development are created separately for each municipality in the district (Table 3, showing only one municipality), and their numerical transformation and processing is performed by means of MCDA, specifically ELECTRE [7] and VICOR [8] methods, which ultimately results in a ranking of economic branches that ought to be developed in each municipality (Table 4).

Table 2. Comparative analysis of sustainable development solution rankings for the municipalities of the Toplica District.

\begin{tabular}{|c|c|c|c|c|}
\hline \multirow[b]{2}{*}{ Municipality-alternative } & \multicolumn{4}{|c|}{ Sustainable development rank } \\
\hline & \multirow{2}{*}{ Kuršumlija, $a_{1}$} & \multirow{2}{*}{ Blace, $a_{2}$} & \multirow{2}{*}{ Prokuplje, $a_{3}$} & \multirow{2}{*}{ Žitorađa, $\mathrm{a}_{4}$} \\
\hline Ranking method & & & & \\
\hline ELECTRE & 2,3 & 2,3 & 1 & 4 \\
\hline VICOR & $2,3,4$ & $2,3,4$ & 1 & $2,3,4$ \\
\hline Adopted rank & 2,3 & 2,3 & 1 & 4 \\
\hline
\end{tabular}


Table 3. Initial decision matrix for sustainable economic development of municipalities in the Toplica District -Municipality of Kuršumlija [6,9].

\begin{tabular}{|c|c|c|c|c|c|c|}
\hline \multicolumn{2}{|c|}{ Alternatives of development } & Agriculture & Livestock breeding & Processing industry & Services & \\
\hline \multicolumn{2}{|l|}{ Criterion } & $a_{1}$ & $\mathrm{a}_{2}$ & $a_{3}$ & $\mathrm{a}_{4}$ & $\mathrm{a}_{5}$ \\
\hline Active population & $\max$ & 580 & 200 & 3109 & 1213 & 655 \\
\hline \multicolumn{7}{|c|}{ Agricultural land } \\
\hline Arable land and gardens (ha) & $\max$ & 3000 & 400 & 1000 & 50 & 45 \\
\hline Orchards and vineyards (ha) & $\max$ & 1510 & 0 & 300 & 10 & 18 \\
\hline Meadows and pastures (ha) & $\max$ & 1000 & 6000 & 543 & 50 & 50 \\
\hline \multicolumn{7}{|c|}{ Use of natural resources } \\
\hline Forests (ha) & $\min$ & 20 & 50 & 1000 & 10 & 10 \\
\hline $\begin{array}{c}\text { Water } \\
\left(\mathrm{x} 10^{3} \mathrm{~m}^{3} / \text { year }\right)\end{array}$ & $\min$ & 2.5 & 0.45 & 1.0 & 0.3 & 0.5 \\
\hline $\begin{array}{l}\text { Available machinery } \\
\text { (no. of tractors) }\end{array}$ & $\max$ & 500 & 250 & 100 & 20 & 20 \\
\hline
\end{tabular}

Sources: RZS (Statistical Office of the Republic of Serbia), 2011, Belgrade; Author

Table 4. Comparative analysis of multi-criteria solutions regarding the ranking of economic branches in the development of municipalities of the Toplica District.

\begin{tabular}{|c|c|c|c|c|c|c|c|c|c|c|c|c|c|}
\hline & \multicolumn{9}{|c|}{ Ranks of economic branches of development } \\
\hline Municipality & \multicolumn{3}{|c|}{ Kuršumlija } & \multicolumn{3}{c|}{ Blace } & \multicolumn{3}{c|}{ Prokuplje } & \multicolumn{3}{c|}{ Žitorađa } & \multicolumn{1}{c|}{ Toplica } \\
District \\
\hline Economic branch
\end{tabular}

Source: Author (El - ELECTRE method; Vc - VICOR method; C - compromise solution)

\section{Conclusions}

The results of ranking of multiple alternative solutions with the use of MCDA methods to determine the state of sustainable development in Toplica District municipalities and the economic branches to be developed in them highlight the most favorable alternative (solution). The offered alternative is ranked first with sufficient advantage over other ranked solutions. The results thus obtained allow the decision makers to use them as core guidelines when creating an actual and feasible plan of sustainable development for their community. The presented model of factor analysis for planning the development of municipalities and the entire region based on sustainability principles was used to analyze multiple influencing factors with multiple possible alternative solutions for development.
In order to rank the solutions, and according to an initial decision matrix, at least two multi-criteria decision analysis methods needed to be used, yielding the end result in the form of rankings and proposals of the first-ranked alternative as the most favorable solution for the analyzed problem. The results obtained in the examples showed that this methodology is also suitable for and practically applicable to other multi-criteria problems pertaining to regional economic, social, and environmental development. The sustainability of development in relation to the available natural resources of the region can be planned and implemented responsibly provided that there is a mechanism in place to efficiently monitor and control the process. It was shown that the presented factor analysis model can be used for these purposes. 


\section{Conflict of Interest}

The authors declare no conflict of interest.

\section{Acknowledgements}

The part of this research is conducted under the auspices of Ministry of Science and Technological Development, Republic of Serbia.

\section{References}

1. STOJANOVIĆ R. Optimalna strategija privrednog razvoja (Optimal Strategy of Economic Development), Savremena administracija Beograd, 27, 1986 [In Serbian].

2. VOJNOVIĆ B., CVIJANOVIĆ D., RODICA B. Faktori regionalnog i lokalnog ekonomskog razvoja (Factors of Regional and Local Economic Development), Institute for Agricultural Economics, Beograd, 2013 [In Serbian].

3. OPRICOVIĆ S. Višekriterijumska optimizacija sistema $\mathrm{u}$ građevinarstvu (Multi-criteria Optimization in Construction), Faculty of Civil Engineering, Beograd, pp. 119-171, 1998 [In Serbian].

4. MILENKOVIĆ M. Održiv razvoj opština Topličkog okruga - stanje i perspektive (Sustainable Development of Municipalities in Toplica District - State and Prospects), Scientific conference: Regional development and demographic flows of Southeastern European countries, Niš, 265, 2018 [In Serbian].

5. MILENKOVIĆ M. Struktura stanovništva kao faktor održivog razvoja Topličke oblasti (Demographic structure as a Factor of Sustainable Development of the Toplica District), Scientific conference: Regional development and demographic flows of Southeastern European countries, Niš, 513, 2015 [In Serbian].

6. RZS (Statistical Office of the Republic of Serbia), Opštine i regioni u Republici Srbiji (Municipalities and Regions in the Republic of Serbia), Official Gazette of the Republic of Serbia, Beograd, pp. 222-287, 2016 [In Serbian].

7. BERNARD R. Classement et choixen presence de points devue multiples (la methode ELECTRE), Revned 'informatique et rechercheoperationelle), 6 (8), 57, 1968.

8. OPRICOVIĆ S., TYENG G.-H. Extended VICOR method in comparison with outranking methods, European Journal of Operational Research 178, 514-529, 2007.

9. MILENKOVIĆ M. Vodni resursi - faktor održivog razvoja Topličke oblasti (Water Resources - a Factor of Sustainable Development of the Toplica District), Scientific conference: Regional development and demographic flows of Southeastern European countries, Faculty of Economics Niš, 287, 2016 [In Serbian].

10. The World Commission on Environment and Development, "Our common Future", Oxford, New York, Oxford University Press, 1997.

11. Zakon o zaštiti životne sredine (Law on Environmental Protection), Official Gazette of the Republic of Serbia, No. 135/2004,36/2009,72/2009,43/2011, Beograd, 2004, 2009, 2011.

12. Nacionalna strategija održivog razvoja Republike Srbije [National Sustainable Development Strategy of the Republic of Serbia], Official Gazette of the Republic of Serbia, No. 57/2008, 14, 2008.

13. Nacionalna strategija održivog korišćenja prirodnih resursa i dobara (National Strategy for Sustainable Use of Natural Goods and Resources). Official Gazette of the Republic of Serbia, No. 32/2012 Beograd, 2012.

14. Government of the Republic of Serbia, Public Policy Secretariat, Srbija i Agenda 2030 (Serbia and Agenda 2030), Beograd, 2019.

15. FRANKOWSKI P., ZBIERSKA J., STANSISYEWSKI R., KAYZER D. Effect of Newly Created Water Reservoirs on Agricultural Landscape Stability, Pol. J. Environ. Stud. 28 (5), 3173, 2019.

16. GOLUMBEANU M., NENCIU M., TEOHAREVA M., STEPANOVA K., RUBEL O., DYACHENKO A., GORIUP N., GILCA A., BILASHVILI K. Environmental sustainable tourism within the black sea region, J Environ Prot. Ecol. 15 (2), 574, 2014. 
